\title{
Response time, waiting time and service quality in emergency department
}

\author{
Nur Hidayat ${ }^{1}$, Ahsan Ahsan ${ }^{2}$, Masruroh Rahayu ${ }^{3}$, Retno Lestari ${ }^{4}$ \\ ${ }^{1}$ Master Program of Nursing, Faculty of Medicine, University of Brawijaya, Indonesia \\ ${ }^{2,4}$ Nursing Science Program, Faculty of Medicine, University of Brawijaya, Indonesia \\ ${ }^{3}$ Department of Neurology, Faculty of Medicine, University of Brawijaya, Indonesia
}

\begin{tabular}{l} 
Article Info \\
\hline Article history: \\
Received Mar 23, 2020 \\
Revised May 16, 2020 \\
Accepted Jun 30, 2020 \\
\hline Keywords: \\
Emergency department \\
Public hospital \\
Response time \\
Service quality \\
Waiting time
\end{tabular}

Article Info

icle history:

Received Mar 23, 2020

Revised May 16, 2020

Keywords

Emergency department

Waiting time

\begin{abstract}
Response time and waiting time were key performance indicators in the emergency department of a hospital. This study will shed light on important factors contributing to service quality in emergency department of Indonesian public hospital by utilizing a cross-sectional design. About 117 patients were selected by simple random sampling techniques. Data observation sheets and a modified service quality instrument were used to measure health services in this department. Findings revealed that $83.8 \%$ patients felt satisfied with the services provided by emergency staff. Based on Kendall's Tau test, waiting time had a significant relationship with service quality $(p<0.05)$ compared to response time $(p>0.05)$. The results of logistic regression test showed that waiting time had a higher value for $\operatorname{Exp}(B)=3.522$. In conclusion, waiting time was the most important factor affecting service quality in emergency department of Indonesian public hospital.
\end{abstract}

This is an open access article under the CC BY-SA license.

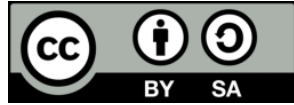

\section{Corresponding Author:}

Nur Hidayat,

Master Program of Nursing,

Faculty of Medicine, University of Brawijaya,

Jl. Veteran-Malang, Jawa Timur, 65145, Indonesia.

Email: nhidayat.ub@gmail.com

\section{INTRODUCTION}

Hospital service quality was defined as patient judgment concerning overall service excellence in the hospital. It described the gap between patient perceptions and expectations towards the provided health services [1-2]. Perceived service quality had a positive correlation with hospital preferences, reference sources, sex differences, educational attainment, health quality, and wait times in the health services ( $p>.05$ ) [3]. Other factors, such as sociocultural and patient background information affected patient satisfaction and patient retention as well [4]. Therefore, health care institutions should optimize its benefits and reduce the risks by providing continuity of care, and improving service outcomes, leading to increased patient's satisfaction as well as hospital profits [5-7]. Many factors have been shown to improve service quality in emergency department. Among these were response time, waiting time, health care costs, hospital facilities, and health care staff competence [8-10].

Response time and waiting time were key performance indicators in the emergency department of a hospital. Response time was the time needed for health care staff to arrive at the patient's location to give health services; on the other hand, waiting time was the period of time that patient spends waiting for emergency services. The total average of waiting time in emergency department was around 210 minutes, which consist of time spent from for triage 5 minutes, doctor assessment for 6 minutes, and clinical 
evaluation for leaving this department about180 minutes [11-14]. Ideally, emergency response time was less than 8 minutes, as this will improve the odds of patient survival (adjusted $\mathrm{OR}=1.3,95 \% \mathrm{CI}=1.00-1.69$ ) [15]. Improving response time and waiting time was related to better patient satisfaction, shorten length of stay, increased life expectancy, decreased mortality rates, and overall hospital service quality [16-18].

The majority of people nowadays used public hospitals because their payment for health services comes from national health insurance. Yet, patient felt that the care provided by Indonesian public hospitals was less than they expected. Longer waiting time, health care staff shortages, complexities in health care facilities, and incompetent health care staff were recorded as factors related to service quality in Indonesian public hospital. These factors also influenced patient satisfaction and patient values on health services $[19,20]$. Emergency department as the first part of hospital patient management should improve the quality of patient service by minimizing average response time and waiting time. Indonesian public hospital could also negotiate with national health insurance to offer a wide range of care services including prescribed various drugs so health care provider could manage patient conditions more effectively. Previous studies presents relatively limited data on this frontline unit of the hospital. This study therefore will shed light on important factors contributing to service quality in emergency department of Indonesian public hospital. Providing better service quality in the public hospital influences patient satisfaction and overall patient experience in hospitals.

\section{RESEARCH METHOD}

A cross-sectional design was utilized to explain important factors contributing to service quality in emergency department of Indonesian public hospital. About 117 patients in emergency department were selected by simple random sampling techniques. Data was collected before patient left the department, in one public hospital (January-February 2020) which was located in Central Java. Respondents received all information regarding the study and signed a consent form.

Data observation sheets and a modified service quality instrument based on standard operating procedure in the hospital were used to measure health services in emergency department. Confounding factors in this study were controlled by employing as simple random sampling to select representative samples from a population; and logistic regression was used to adjust other co-variants in this study. A research ethical approval was obtained from Ethical Board of General Hospital in Kudus, Central Java (No.003/EP/01/2020). Analysis of data used Kendall's Tau test and logistic regression to describe factors related to service quality in emergency department.

\section{RESULTS AND DISCUSSION}

Findings showed the characteristics of respondents based on age, sex, education, occupation, heath financing and triage level that can be seen in Table 1. Additionally, Table 2 illustrated the results of Kendall's Tau test to explain the correlation between response time, waiting time, and service quality in the hospital. Table 3 described the analysis of logistic regression test.

\subsection{Characteristics of respondent}

As can be seen in Table 1, almost half of respondents aged over 60 years old (47\%), more than half of respondents were female $(52.1 \%)$, about one third of respondents had completed junior high school $(32.5 \%)$ and senior high school (37.6\%). In addition to this, $60.7 \%$ of respondents worked as private employees, and $88 \%$ of respondents used national health insurance. Commonly, emergency patients were in $2^{\text {nd }}$ priority $(39.3 \%)$ and $3^{\text {rd }}$ priority $(44.4 \%)$ triage level respectively.

Older adult was found as frequent users of emergency department $(\mathrm{OR}=1.5,95 \% \mathrm{CI}=1.4-1.7)$ as they have issues regarding the continuity and coordination of care. Previous study showed that 59\% of respondents were in green level or $3^{\text {rd }}$ priority and $39 \%$ of elderly were in red code or $2^{\text {nd }}$ priority of triage level [21]. In line with another study, female, private employees, and senior high school education level were also reported as the largest proportion of emergency patient status [22]. Most emergency patients used national health insurance to help cover their medical care costs and almost half of respondents (48\%) recognized their health rights and obligations [23]. National health insurance was known as the most favorable health insurance used in the public hospital which covered a variety of medical benefits for all Indonesian citizens [24].

\subsection{Correlations between response time, waiting time and service quality}

This study found that $52.1 \%$ of respondents dissatisfied with the response time in emergency department as shown in Table 2. On the other hand, most patients felt satisfy with the average waiting time (70.9\%). However, most patients felt satisfy with overall service quality provided by emergency staff. 
Findings revealed that $83.8 \%$ patients felt more satisfied with the emergency services. This suggests that some conditions stated by $16.2 \%$ of 117 patients have to be improved upon to ensure that the public hospital achieved total satisfaction for all their patients. Based on Kendall's Tau test that can be seen in Table 3, waiting time had a significant relationship with service quality $(\mathrm{p}<0.05)$ compared to response time $(\mathrm{p}>0.05)$.

Table 1. Characteristics of respondent

\begin{tabular}{lcc}
\multicolumn{1}{c}{ Categories } & $\begin{array}{c}\text { Distribution of Frequency }(\mathrm{N}=117) \\
\mathrm{n}\end{array}$ \\
\hline Age & 32 & 27.4 \\
$>$ 20-40 years old & 30 & 25.6 \\
41-60 years old & 55 & 47.0 \\
$>$ 60 years old & & \\
Sex & 56 & 47.9 \\
Male & 61 & 52.1 \\
Female & & \\
Education & 30 & 25.6 \\
Elementary & 38 & 32.5 \\
Junior High School & 44 & 37.6 \\
Senior High School & 5 & 4.3 \\
Bachelor & & \\
Occupation & 28 & 23.9 \\
Unemployed & 71 & 60.7 \\
Private employee & 13 & 11.1 \\
Public employee & 5 & 4.3 \\
Entrepreneur & & \\
Health financing & 14 & 12.0 \\
Self-funded & 103 & 88.0 \\
National health insurance & & \\
Triage level & 9 & 7.7 \\
$1^{\text {st }}$ Priority (P1) & 46 & 0.3 \\
$2^{\text {nd }}$ Priority (P2) & 52 & \\
$3^{\text {rd }}$ Priority (P3) & 10 & \\
$4^{\text {th }}$ Priority (P4) & & \\
$5^{\text {th }}$ Priority (P5) & & \\
\hline
\end{tabular}

Table 2. Distribution of frequency response time, waiting time and service quality

\begin{tabular}{lcc}
\hline \multicolumn{1}{c}{ Categories } & $\begin{array}{c}\text { Distribution of Frequency }(\mathrm{N}=117) \\
\mathrm{n}\end{array}$ & $\%$ \\
\hline Response time & & 52.1 \\
Not satisfy & 61 & 47.9 \\
Satisfy & 56 & \\
Waiting time & & 29.1 \\
Not satisfy & 34 & 70.9 \\
Satisfy & 83 & \\
Service quality & & 16.2 \\
Not satisfy & 19 & 83.8 \\
Satisfy & 98 & \\
\hline
\end{tabular}

Table 3. Kendall's tau test results

\begin{tabular}{ccc}
\hline Relationships between variables & Correlation Coefficients & P value \\
\hline Response time and service quality & 0.004 & 0.963 \\
Waiting time and service quality & 0.229 & 0.014 \\
\hline
\end{tabular}

Studies showed that public hospital had a poor response time due to health care staff shortages, incompetent staff, and unhealthy hospital environment. Health care staff also felt overloaded at work and they had to overcome considerable challenges within the hospital, in addition to this lack of competent health care staff and hospital facilities caused additional burden [25, 26]. Response time was a fundamental indicator in emergency department, and this could be achieved by adequate triage knowledge and skills as well as accessing to appropriate information and technology in emergency department [27]. Response time in emergency services had a correlation with patient's survival after cardiac arrest [28]. However, in another study by Weiss et al. stated that response time less than 8 minutes did not affect morbidity and mortality rates in cardiac arrest patients as this period of time only applicable to patient complaining of chest discomfort, breath problems, open wound/trauma, and accidents [29]. In another study, response time which was less than 17 minutes in pre hospital area could increase $87 \%$ chance of patient's survival. Factors related to increased patient's survival include patient's responsiveness and response of time in pre-hospital 
care $<17$ minutes [30]. A study by Mutiasari et al. explained that with an ideal response time in emergency department of Indonesian hospital $<5$ minutes, there was a significant relationship between response time and patient satisfaction with $\mathrm{p}$ value $<0.05$. Patient satisfaction was described as an important indicator in hospital service quality [31].

In this study, waiting time had a significant relationship with service quality and $70.9 \%$ stated that they satisfied with the period of waiting time in emergency department. A number of factors influenced waiting time such as rate of arrival, provided health services, period of time, and management quality [32]. This study is in line with Al-Harajin et al. which identified patient satisfaction with the period of waiting time $(\mathrm{M} \pm \mathrm{SD}=38.4 \pm 6.63)$ and overall waiting time $(\mathrm{p}<0.01)$ [33]. Another study argued that it is difficult to overcome patient dissatisfaction, regardless of sufficient facilities and competent staff, therefore they recommend that health care providers should be more empathetic and show respect during interaction with patient. Being empathy improves healthy relationship between patient and health care staff which leads to increased patient satisfaction [34].

\subsection{Logistic regression results}

The results of logistic regression test showed that waiting time had a higher value for $\operatorname{Exp}(\mathrm{B})=3.522$ that can be seen in Table 3. Therefore, the most influencing factors related to service quality in emergency department was the waiting time. Umar et al. investigated that work shifting could be a solution to manage staff shortages and reduce the average waiting time by $2.13 \mathrm{~h}$ (Mean difference $=-2.13 \mathrm{~h}, 95 \% \mathrm{CI}=-2.44:-1.82 \mathrm{~h}$, $\mathrm{p}<0.001$ ) [35]. Previous study in an emergency department in Hongkong found that the average waiting time was about 2 hours. Longer waiting time was caused by the fact that people preferred to go to public hospital [36]. This condition also happened in Indonesia as most people are more likely to check their medical conditions in public hospital as they can use their national health insurance and received a subsidy for the prescribed medications.

Table 4 explained the equation of $\mathrm{Y}=\mathrm{constant}+\mathrm{aX} 1+\mathrm{aX} 2, \mathrm{Y}=0.946+(-0.194$ response time $)+$ (1.268 the waiting time). The result of this regression logistic equation can also be used to calculate the distribution of the response time and the waiting time for patients in emergency department. For example, if the patient was given an initial 5 minutes assessment, patient whose clinical conditions was in $3^{\text {rd }}$ priority (P3), and 30 minutes' waiting time. The regression equation modeling was as follow:

$\mathrm{Y}=$ constant $+\mathrm{aX} 1+\mathrm{aX} 2$

$\mathrm{Y}=0.946+(-0.194$ response time $)(5)+(1.268$ waiting time $)(30)$

$\mathrm{Y}=0.946+-0.970+38.04$

$\mathrm{Y}=38.016$ minutes

Table 4. Logistic regression test results

\begin{tabular}{|c|c|c|c|c|c|c|c|c|c|}
\hline & & \multirow{2}{*}{ B } & \multirow{2}{*}{ S.E. } & \multirow{2}{*}{ Wald } & \multirow{2}{*}{ df } & \multirow{2}{*}{ Sig. } & \multirow{2}{*}{$\operatorname{Exp}(B)$} & \multicolumn{2}{|c|}{$95 \% \mathrm{CI}$ for $\operatorname{Exp}(\mathrm{B})$} \\
\hline & & & & & & & & Lower & Upper \\
\hline \multirow{3}{*}{ Step $1^{\mathrm{a}}$} & The response time & -0.194 & 0.526 & 0.135 & 1 & 0.713 & 0.824 & 0.294 & 2.311 \\
\hline & The waiting time & 1.268 & 0.527 & 5.792 & 1 & 0.016 & 3.552 & 1.265 & 9.973 \\
\hline & Constant & 0.946 & 0.424 & 4.967 & 1 & 0.026 & 2.574 & & \\
\hline
\end{tabular}

a. Variable(s) entered on step 1: The response time, the waiting time

Service quality in public hospital was also affected by five components: responsiveness, reliability, empathy, tangibles, and assurance. The comparison scores of overall service quality between private and public hospital were -0.24 and -0.66 . Reliability was the highest component of service quality showed in private hospital, while responsiveness had the largest score aspect in public hospital [37]. Improving service quality in the public hospital could be achieved by paying particular attention to enhancing staff competencies, advancing hospital technology and resources, providing effective communication, managing sufficient health funding [38-41]. Issues regarding the complexity of service quality in the public hospital need to be solved, consequently emergency department has a responsibility to reduce waiting time and ensure faster response time so patient will feel more satisfy with the provided services in public hospital.

\section{CONCLUSION}

A correlation coefficients showed that more than half of respondents dissatisfied with the response time whereas most patients felt satisfy with the average waiting time in emergency department. On the other hand, most patients felt satisfy with overall service quality provided by emergency staff. Based on the logistic regression analysis, waiting time had a higher value for $\operatorname{Exp}(B)=3.522$. In conclusion, waiting time was the most important factor affecting service quality in emergency department of Indonesian public hospital. 


\section{ACKNOWLEDGEMENTS}

I would like to express my gratitude to AA dan MR for their continuous advice and supports in guiding me through this study. Thank you to RL for creating many collaborations between us during the study.

\section{REFERENCES}

[1] Lupo, T., "A fuzzy framework to evaluate service quality in the healthcare industry: An empirical case of public hospital service evaluation in Sicily," Applied Soft Computing, vol. 40, pp. 468-478, 2016.

[2] Setyawan, F.E.B., et al., "Medical staff services quality to patients satisfaction based on SERVQUAL dimensions," International Journal of Public Health Science (IJPHS), vol. 8, no. 1, pp. 51-57, 2019.

[3] Abbasi-Moghaddam, M.A., et al., "Evaluation of service quality from patients' viewpoint," BMC Health Serv Res., vol. 19, no. 1, pp. 170, 2019.

[4] Thawesaengskulthai, N., et al., "Hospital service quality measurement models: patients from Asia, Europe, Australia and America," Total Quality Management \& Business Excellence, vol. 26, no. 9, pp. 1-13, 2015.

[5] Lee, D., Kim, K.K., "Assessing healthcare service quality: a comparative study of patient treatment types," International Journal of Quality Innovation, vol. 3, no. 1, pp. 1-15, 2017.

[6] Bustamante, P., et al., "Patient evaluation of quality of emergency department care and associated factors," Emergencias, vol. 25, no. 3, pp. 171-176, 2013.

[7] Gholami, M., et al., "Services quality in emergency department of Nemazee Hospital: Using SERVQUAL model," J. Health Man \& Info., vol. 3, no. 4, pp. 120-126, 2016.

[8] Alsawat, I.T., "Patient Satisfaction with Service Quality in Emergency Department of Public Hospitals in KSA," International Journal of Medical Research \& Health Sciences (IJMRHS), vol. 8, no. 10, pp. 102-110, 2019.

[9] El Sayed, M.J., "Measuring quality in emergency medical services: a review of clinical performance indicators," Emerg Med Int., pp. 1-7, 2012.

[10] Byczkowski, T.L., et al., "The pediatric emergency department care experience: A quality measure," Patient Experience Journal, vol. 5, no. 2, pp. 32-53, 2018.

[11] Cabral, E.L.D.S., et al., "Response time in the emergency services. Systematic review," Acta Cir. Bras., vol. 33, no. 12, pp. 1110-1121, 2018.

[12] Fazl Hashemi, S.M.E., et al., "Patient waiting time in hospital emergency departments of Iran: A systematic review and meta-analysis," Med J Islam Repub Iran, vol. 31, no. 79, pp. 1-8, 2017.

[13] Hajzargarbashi, E., et al., "Waiting Time for Specialist Consultation and Visit Requested in the Emergency Department; a Cross-Sectional Study," Adv J Emerg Med., vol. 3, no. 2, pp. e15, 2019.

[14] Amina, S., et al., "Measuring and Analyzing Waiting Time Indicators of Patients' Admitted in Emergency Department: A Case Study," Glob. J. Health Sci., vol. 8, no. 1, pp. 143-149, 2015.

[15] Blanchard, I. E., et al., "Emergency Medical Services Response Time and Mortality in an Urban Setting," Prehospital Emergency Care, vol. 16, no. 1, pp. 142-151, 2012.

[16] Perez, M., "Response Time to the Emergency Department (ED) and Its Effect on Patient Flow and Hospital Outcomes," Chest, vol. 148, no. 4, pp. 481A, 2015.

[17] Byrne, J. P., et al., “Association Between Emergency Medical Service Response Time and Motor Vehicle Crash Mortality in the United States," JAMA Surgery, vol. 154, no. 4, pp. 286-293, 2019.

[18] Chen, X., et al., "Factors Influencing the Emergency Medical Service Response Time for Cardiovascular Disease in Guangzhou, China. Current Medical Science, vol. 39, pp. 463-471, 2019.

[19] Sandhyaduhita, P., "Hospital Service Quality from Patients Perspective: A Case of Indonesia," International Journal of E-Health and Medical Communications, vol. 7, no. 4, pp. 48-61, 2016.

[20] Surydana, L., "Service Quality, Customer Value and Patient Satisfaction on Public Hospital in Bandung District, Indonesia," International Review of Management and Marketing, Econjournals, vol. 7, no. 2, pp. 187-192, 2017.

[21] Legramante, J. M., et al., "Frequent Use of Emergency Departments by the Elderly Population When Continuing Care Is Not Well Established," PloS one, vol. 11, no. 12, 2016.

[22] Kristiani, Y., et al., "The Relationship between Waiting Time and Priority 3 Patient Satisfaction in the Emergency Installation of Waluya Sawahan Hospital Malang (In Bahasa: Hubungan Waiting Time Dengan Kepuasan Pasien Prioritas 3 Di Instalasi Gawat Darurat RS Waluya Sawahan Malang)," Jurnal CARE, vol. 3, no. 1, pp. 33-38, 2015.

[23] Makisurat, J.G., et al., "Implementation of Emergency Services for BPJS Health Participants in the Ratu Aji Putri Botung Regional General Hospital in terms of Minister of Health Decree Number 856 / Menkes / Sk / Ix / 2009 Concerning Hospital Emergency Installation (IGD) Standards (In Bahasa : Pelaksanaan Pelayanan Gawat Darurat Bagi Peserta BPJS Kesehatan Di Rumah Sakit Umum Daerah Ratu Aji Putri Botung Ditinjau Dari Keputusan 
Menteri Kesehatan Nomor 856/Menkes/Sk/Ix/2009 Tentang Standar Instalasi Gawat Darurat (IGD) Rumah Sakit)," SOEPRA Jurnal Hukum Kesehatan, vol. 4, no. 1, pp. 112-131, 2018.

[24] LaCalle, E.J., Rabin, E., "Frequent users of emergency departments: the myths, the data, and the policy implications," Ann Emerg Med., vol. 56, no. 1, pp. 42-48, 2010.

[25] Aman, B., Abbas, F., "Patient's perceptions about the service quality of public hospitals located at District Kohat," Journal of the Pakistan Medical Association, vol. 66, no. 1, pp. 72-75, 2016.

[26] Irfan, S.M., et al., "Patient Satisfaction and Service Quality of Public Hospitals in Pakistan: An Empirical Assessment," Middle-East Journal of Scientific Research, vol. 12, no. 6, pp. 870-877, 2012.

[27] Al-Shaqsi, S.Z.K., "Response time as a sole performance indicator in EMS: Pitfalls and solutions. Open Access Emerg Med., vol. 2, pp. 1-6, 2010.

[28] Goto, Y., et al., "Relationship Between Emergency Medical Services Response Time and Bystander Intervention in Patients With Out-of-Hospital Cardiac Arrest. Journal of the American Heart Association, vol. 7, no. 9, e007568, 2018.

[29] Weiss, S., et al., "Does Ambulance Response Time Influence Patient Condition among Patients with Specific Medical and Trauma Emergencies?,” Southern Medical Journal, vol. 106, no. 3, pp. 230-235, 2013.

[30] Mahama, M., et al., "Emergency response time and pre-hospital trauma survival rate of the national ambulance service, Greater Accra (January-December 2014). BMC Emerg Med., vol. 18, no. 1, pp. 33, 2018.

[31] Mutiarasari, D.M., et al., "Response Times and Patient Satisfaction in Emergency Room at Anutapura General Hospital, City of Palu," Journal of Current Medical Research and Opinion, vol. 2, no. 05, pp. 152-157, 2019.

[32] Sarkar, A., et al., "Improvement of service quality by reducing waiting time for service," Simulation Modelling Practice and Theory, vol. 19, no. 7, pp. 1689-1698, 2011.

[33] Al-Harajin, R.S., et al., "The association between waiting time and patient satisfaction in outpatient clinics: Findings from a tertiary care hospital in Saudi Arabia," J Family Community Med., vol. 26, no. 1, pp. 17-22, 2019.

[34] Xie, Z., Or, C., "Associations between Waiting Times, Service Times, and Patient Satisfaction in an Endocrinology Outpatient Department: A Time Study and Questionnaire Survey," INQUIRY: The Journal of Health Care Organization, Provision, and Financing, vol. 54:1-10, doi: 10.1177/004695801773952, 2017.

[35] Umar, N.A., et al., "Reduction of client waiting time using task shifting in an anti-retroviral clinic at Specialist Hospital Bauchi, Nigeria," J Public Health Afr., vol. 2, no. 1, pp. e2, 2011.

[36] Tsui, Y., Fong, B., "Waiting time in public hospitals: case study of total joint replacement in Hong Kong," Public Administration and Policy: An Asia-Pacific Journal, vol. 21, no. 2, pp. 120-133, 2018.

[37] Yousapronpaiboon, K., Johnson, W.C., "A Comparison of Service Quality between Private and Public Hospitals in Thailand," International Journal of Business and Social Science, vol. 4, no. 11, pp. 176-184, 2013.

[38] Wanjau, K.N., et al., "Factors Affecting Provision of Service Quality in the Public Health Sector: A Case of Kenyatta National Hospital," International Journal of Humanities and Social Science, vol. 2, no. 13, pp. 114-125, 2012.

[39] Mosadeghrad, A.M., "Factors influencing healthcare service quality," Int J Health Policy Manag., vol. 3, no. 2, pp. 77-89, 2014.

[40] Hussain, A., et al., "What Factors Affect Patient Satisfaction in Public Sector Hospitals: Evidence from an Emerging Economy. International Journal of Environmental Research and Public Health, vol. 16, no. 6, pp. 994, 2019.

[41] Roy, J., et al., "A Rough Strength Relational Dematel Model for Analyzing The Key Success Factors of Hospital Service Quality,” Decision Making: Applications in Management and Engineering, vol. 1, no.1, pp. 121-142, 2018. 